The International Journal of Indian Psychology

ISSN 2348-5396 (e) | ISSN: 2349-3429 (p)

Volume 3, Issue 4, No. 60, DIP: 18.01.085/20160304

ISBN: 978-1-365-26308-8

http://www.ijip.in | July-September, 2016

\title{
Police: A Savior to Drug Addicts
}

\author{
Rashi Sekhri ${ }^{1 *}$
}

\section{ABSTRACT}

Since independence, our society is been ingested up by abuses like drug addiction, cyber crimes, sexual assaults, gambling etc to a great extent. Above all, Drugs are the termites for our India. The fragmentation of old joint family system, absence of parental love, process of industrialization, urbanization has led to an increased number of drug trafficking and addiction among youth which has taken a frog leap in our country. Drugs have been classified as an EPIDEMIC by Centre for Disease Control and Prevention. Now it's time for our Indian Police to act like aardwolf to eradicate these termites and makes the addiction free nation. Police (public officers for legal investigations and criminal emergencies) is the most perceptible officials in the criminal justice system that is charged with preventing crime and enforcing the law. This paper focuses on those preventive measures that can be taken by Indian Police to curb drug-addiction from the society. Evidences about the effectiveness of drug education, role plays, awareness campaigns, motivational workshops and extra-curricular activities are discussed which can be considered as nullifiers to obliterate drug abuse. Besides other states in India, Punjab has come under the red alert zone in drug trafficking and addiction. According to 2011 Report on drug abuse and alcoholism in Punjab by Ministry of Youth Affairs and Sports, $40 \%$ of Punjabi youth of age group 15-25 years have fallen to drug-addiction. The literature referred in this paper includes qualitative and quantitative research studies on preventive measures taken in various parts of India which can be of great help to Police in encouraging the land of five rivers that is Punjab, to swipe the flood of drugs from its roots. Laws regarding the drug prevention, counseling programs and their adaptability by the society have also been studied.

Keywords: Drug-Addiction, Role Of Indian Police, Preventive Measures,

"Addiction comes from the Latin word addictus, the past participle of "addicere", which means to bind a person to one thing or another. Drug addiction is a chronic, often relapsing brain disease that causes compulsive drug seeking and use, despite harmful consequences to the drug addict and those around them. It usually implies a strong (Psychological) and (Physical)

\footnotetext{
${ }^{1}$ Masters in Commerce, Department of Commerce, Apeejay College of fine arts, Jalandhar, India *Responding Author

(C) 2016, R Sekhri; licensee IJIP. This is an Open Access Research distributed under the terms of the Creative Commons Attribution License (http://creativecommons.org/licenses/by/2.0), which permits unrestricted use, distribution, and reproduction in any Medium, provided the original work is properly cited.
} 


\section{Police: A Savior to Drug Addicts}

Dependency resulting in a withdrawal syndrome when use of the drug is stopped. Many definitions place primary stress on psychological factors, such as a loss of self-control and overpowering desires, i.e., addiction is any state in which one craves for the use of a drug and uses it frequently (Nelson et al., 1982). Drug addiction has been defined as the condition characterized by prodigious desire to continue taking a drug to the extent one has become habituated through repeated consumption as it produces a particular effect, usually an alteration of mental status. Addiction is usually accompanied by an urge to take drugs, a tendency to increase the dose, a psychological and physical dependency and detrimental consequences for individual and society. It is an intense craving for a drug. It is a complex disease, and quitting takes more than good intentions or a strong will. The various symptoms of drug addiction are enslavement towards drug intake, deprived control in limiting the intake, emergence of negative emotional states (e.g., dysphoria, anxiety, and irritability). Other symptoms of drug addiction can be: taking uncharacteristic risks, (such as driving under the influence or sexually risky behavior), anger outbursts, acting irresponsibly and overall attitude change, deterioration of physical appearance and grooming etc.

\section{REVIEW OF LITERATURE}

As the time passes through, the range of drugs increased to an alarming level. Drugs like Narcotics: analgesics, morphine, opium, heroin, brown sugar, and cocaine, are frequently abused. In India, there are many targeted states like Punjab, Haryana, and Maharashtra who have been in the great victimized group of drug addiction but the most vulnerable state is Punjab.

In a newspaper named Hindustan Times (HT) page 2 on $26^{\text {th }}$ June, 2016, a mind boggling news was published that a 20 year old youth died due to drug overdose. This boy used to inject himself with different kinds of drugs and his whole body bored marks of injections. Few days back he was deteriorated due to overdose and was admitted to an Anti Drug Addiction Centre where he was saved but unfortunately he quit his life on $26^{\text {th }}$ June, 2016.

In this June 2015 report India Spend has cited this data to convey the extent of Punjab’s drug problem as Two studies in the village of Chhajli in south-eastern Punjab district of Sangrur, 32 years apart, show a 9 percentage points rise in the casual/recreational use of drugs (including tobacco, alcohol, opium, cannabis, etc.) from $30 \%$ in 1979 to $39 \%$ in 2011 . Based on his experience, Amarpreet Singh Deol, chairman of the Guru Nanak Charitable Trust, an NGO working with addicts, estimated that "about half of males of the productive age group (15 to 60 years) casually use drugs including alcohol, tobacco, poppy husk and other opiates, etc., of who around $10 \%$ cannot do without it for longer than 24 hours.”

During 2011-2012, Punjab’s growth rate slipped to "5.79 per cent - the lowest in the last five years of the Parkash Singh Badal government” due to drug epidemic which has swept across the state. According to many reports it has seen that the problem of drug addiction in Punjab is 


\section{Police: A Savior to Drug Addicts}

linked with many factors like Punjab masculinity, culture of consumption, urbanization and as well as poverty.

According to 2011 report, on drug abuse and alcoholism in Punjab by the Ministry of Youth Affairs and Sports witnessed, " 40 per cent of Punjabi youth in the age group of 15 to 25 years have fallen prey to drugs". At present, more than $75 \%$ of youth in Punjab is hooked to dangerous drugs like heroin, smack, cocaine and many synthetic drugs. Out of these $75 \%$ addicts, about $30 \%$ are HIV-positive people.

In 2004, Punjab was ranked as the "second richest" state in terms of GDP per capita, according to a report by the Confederation of Indian Industry, "with a per capita income of Rs 25,652".

According to the latest report by the Narcotics Control Bureau, Punjab alone has registered 50 percent of the total drug-related cases in the country. But, as pitiful as it may seem, the Akali Dal Government which is led by the Badal family continues to live in a state of denial, even when the names of many of their top leaders have appeared for running the drug nexus.

\section{Adolescence}

Adolescence is a developmental transition between childhood and adulthood. It is one of the most fascinating and complex transitions in the life span. As this period of childhood is very influential and sensitive to all exposures of life, the danger of addiction to drugs is also found very commonly in adolescents. Drug abuse in children and teenagers may pose a greater hazard than in older people. This is because their brains are not yet fully developed. As a result, the brains of young people may be more susceptible to use of drugs and addiction than adult brains. According to National Survey on Drug Use and Health in 2012, factors shoving adolescents towards the intake of drugs are:

o $\quad$ Lack of Parental love and high academic and moral expectations

o School under-achievements

o Low self esteem

o Peer pressure

o Depression

o Divorce

When the above mentioned factors overwhelm the minds of children the bent towards drug addiction starts increasing as these adolescents find those drugs as relaxing element for their minds.

\section{Fascinating road to drug enslavement by youth}

Studies such as the National Survey on Drug Use and Health, formerly called the National Household Survey on Drug Abuse, reported by the Substance Abuse and Mental Health Services 


\section{Police: A Savior to Drug Addicts}

Administration, indicate that some children are already taking drugs from the age of 12 or 13, which likely means that some may begin even earlier. Early abuse includes such drugs as tobacco, alcohol, inhalants, marijuana, and psychotherapeutic drugs. If drug abuse persists into later adolescence, abusers typically become more involved with marijuana and then advance to other illegal drugs, while continuing their abuse of tobacco and alcohol. Studies have also shown that early initiation of drug abuse is associated with greater drug involvement, whether with the same or different drugs. However, both one-time and long-term surveys indicate that most youth do not progress to abusing other drugs. But among those who do progress, their drug abuse history can vary by neighborhood drug availability, demographic groups, and other characteristics of the abuser population.

\section{Elementary factors for drug inclination in Punjab}

1. Rural Element Problem: According to 2011 census, Punjab’s population is distributed somewhat more heavily in urban areas than India's total population, with a $62.5 \%$ rural population and a $37.5 \%$ urban population. In fact, "Punjab is one of the most highly urbanized states in India", yet its population of drug abusers is one of the most-rural compared to those in other Indian states. Equally significant is the fact that Punjab's population of drug abusers is much more high in rural than in general population.

2. Unemployment and Aspiration: A Sociologist, Sandhu, R.S. (2011), reported "Punjabis are very aspirational people, and when their aspirations are not fulfilled, and then they are depressed”. The other set of responses come from users like a 23-year-old engineering student who seems less affected by the lack of opportunities and instead sees drugs as a way to overcome boredom that comes with not having to work. His drug use appears not to be driven by desperation or depression. According to a study conducted jointly by Ludhiana-based organizations Guru Gobind Singh Study Circle and Aas Kiran on 192 drug addicts at Aas Kiran De-addiction Centre, “about three fourth respondents belonged to the age group of 15-35 years”, out of which the majority "were hooked to this deadly habit during 21-25 years of age.

3. Masculinity and Consumption: In addition to youth unemployment, several other Punjab-specific factors such as practices of consumption and the Punjabi sense of masculinity may help explain the growing phenomenon of drug abuse in the state. The desire to enhance sexual prowess, a highly 'macho' form of behavior, is frequently cited by drug abusers. This conveys the link between masculinity and drug addiction in Punjab.

\section{Consequences of drug abuse:}

Adolescent's sexual assault, committing murders, performing theft activities, involvement in anti-social activities harming public and cultural norms of the society. Feel guilty or remorseful about their using but still fail to permanently alter the way they use. The study done by Kalra \& Bansal in 2012, in drug de-addiction centre in Punjab revealed that most of the young married men are prone to drug addiction. 


\section{Police: A Savior to Drug Addicts}

Strict prevention is needed to be scheduled by Indian police to overcome this abuse as it is also leading to criminal records, the number of gang rapes are increasing day by day in India as of effect of drugs which increases the sexual and erotic sensations in males. According to Delhi Psychiatry Journal in 2009, adolescents age ranging between 12 to 16 who have ever used marijuana are more likely at some point to have sold marijuana, carried a handgun, or been in a gang than youth who have never used marijuana. According to, the Indian Police Journal (2008), two cases were found which proves the worst consequences of drug abuse:

Case No 25: My brother says I feel ashamed to address you as my brother and we will be happy without you. My Sister always cursed me for being born in their family. I really do not know how to alter this kind of situation. My brothers and sisters are always making me angry and in return I beat them. Nobody loves me and cares for me.

Case No 36: My sister is always cursing me that only because of me she could not get herself married in a decent family. I don't like my sister. Sometimes she aggravates my anger and I feel like killing her.

\section{Drugs and Environment}

Drug Enforcement Administration (DEA), the federal agency best known for dismantling International and domestic drug trafficking organizations states that drug abuse bears huge costs to society and environment.

\section{Risk factors for Non-Drug users}

The consequences of drug use are not limited to the individuals who take drugs. Even non-users are at risk;

o Drug use costs our society over $\$ 180$ billion a year.

o It harms the global environment.

o Methamphetamine production uses toxic chemicals which seep into the ground and contaminate water sources.

The Amazon region is being depleted by cocoa production. Drugged drivers injure and kill innocent people every year. Terrorist activities are connected to drugs; many organizations raise money for their violent attacks through drug production and trafficking. Children are adversely affected by drugs their parents use or manufacture in their homes. Surveys conducted by MADD (Mothers Against Drunk Driving) and the Liberty Mutual Insurance Company revealed that many teenagers (41 percent) were not concerned about driving after taking drugs. Medical data indicates a connection between drugged driving and accidents. A study of patients in a shocktrauma unit who had been in collisions revealed that 15 percent of those who had been driving a car or motorcycle had been smoking marijuana and another 17 percent had both THC and alcohol in their blood. 


\section{Police: A Savior to Drug Addicts}

\section{Camera-Roll-Action: Police}

The war on drugs is not being won, and it continues to threaten stability and democracy not only in the Andes but throughout the Caribbean as well, where tiny police and military forces are outclassed by the sophisticated equipment in the hands of traffickers passing through the region on the way to their market in this country (Elliott Abrams). With time, the role of the police has expanded and is expanding steadily to areas having larger public interface. The emerging police roles are to protect life and property, to reduce the opportunity to commit crimes, to maintain social order and to protect the individual freedom and privacy. The concept of proactive policing is fast catching up the imagination in modern times across the globe. With the rise in the happenings of criminal activities such as terrorism, theft, and the most prevalent is drug abuse. Indian police act as a significant warrior in eradicating the effect of this evil from our society. To tackle this abuse, Indian police has to tightly fasten their belts and extraordinary efforts should be made to have the competent patrol. In this acrimonious debate about the performance of Indian police there has been little attempt to define specific yardsticks for measuring their performance in India. There should be some strict steps taken by Indian patrol like Police drug de-addiction centre is established on scientific lines and no individual is forcefully admitted there. Further, the information of the patients is kept strictly confidential. The services offered at police drug de addiction centre include, Registration, Motivational assessment and motivational enhancement, detoxification/ Medical review, psychiatric review, individual and group counseling, family counseling, yoga therapies, religious orientation classes, recreational activities and occupational rehabilitation programmes etc.

\section{Drug laws in India}

The National Academy of customs, Excise and Narcotics (NACEN) has been mandated to impart training in the three fields of customs, central excise and narcotics. NACEN has been conducting a number of training programmes on various aspects of drug law enforcement at its Faridabad campus as well as its nine Regional Training Institutes at Delhi, Mumbai, Chennai, Kolkata, Bangalore, Hyderabad, Kanpur, Hazaribagh and Vadodara for drug law enforcement officers of various departments.

\section{NDPS Amendments, 2014}

In early 2014, the NDPS Act was amended for the third time and the new provisions came into force on 1 May 2014. The main features include:

- Creation of a new category of "essential narcotic drugs", which the central government can specify and regulate uniformly throughout the country.

- Widening the objective of the law from containing illicit use to also promoting the medical and scientific use of narcotic drugs and psychotropic substances41 in keeping with the principle of 'balance' between control and availability of narcotic drugs that underpins the international drug control treaties. 


\section{Police: A Savior to Drug Addicts}

- Including the terms "management" of drug dependence and "recognition and approval" of treatment centers, thus allowing for the establishment of legally binding treatment standards and evidence-based medical interventions.

- Making the death penalty discretionary for a subsequent offence involving a certain quantity of drugs under section 31A. The court will have the alternative to impose imprisonment for 30 years under section 31.

- Enhanced punishment for small quantity offences from a maximum of six months to one year imprisonment.

A five-day training programme on Drug Abuse Prevention for officials of SAARC member countries were organized by National Institute of Social Defence, Ministry of Social Justice \& Empowerment at New Delhi from 25 to 29 February, 2008. The Purpose of the Training Programme aimed at:

I. To provide a platform for sharing the drug scenario of Member Countries and their experience in implementation of drug abuse programmes.

II. To provide inputs on various issues relating to drug abuse and available approaches/interventions to deal with menace of drug abuse in view of the social cultural similarities of the region.

III. To explore possibilities for mobilizing and sharing of resources and technical support among all SAARC Member Countries for better implementation of Drug Abuse Prevention Programmes in the region.

\section{Techniques}

The Training Programme used various methodologies in order to make the learning gained in each session more effective. The resource persons used the following methods singularly or in combination in order to communicate the theme of the session in an effective manner:

- Mind Mapping

- Lectures

- Power Point Presentation

- Small Group Activities

- Large Group Interaction

- Brain storming

\section{Effect of collaboration}

Police officers actually perform three roles in fulfilling their law enforcement responsibilities:

o law enforcement,

0 order maintenance, and

o service (Wilson, 1968)

The public and the police themselves have viewed the law enforcement function as the primary and most important task, and little attention was given to the others, which were considered less 


\section{Police: A Savior to Drug Addicts}

important, and not "real law enforcement" . For police to be effective, they must be able to work effectively not only within the operations of the criminal justice system with which they are most closely identified, but also within other social and governmental systems, such as community organizations, government agencies, including local, state, and federal regulatory systems, civil law enforcement systems, mental health systems, public health and emergency medical service systems, government and non-government social service agencies, including those for drug and alcohol treatment and detoxification.

\section{Precautionary measures for drug abuse}

According to National Institute of Drug abuse, various preventive programs should be introduced to reverse or reduce the risk factors of substance abuse (Hawkins et al., 2002). Prevention programs should address all forms of drug abuse, alone or in combination, including the underage use of legal drugs (e.g., tobacco or alcohol); the use of illegal drugs (e.g., marijuana or heroin); and the inappropriate use of legally obtained substances (e.g., inhalants), prescription medications, or over-the-counter drugs (Johnston et al., 2002).

Various popular acts have been established to stop the drug abuse in our Indian society, the most vanquished act is Narcotic Drugs and Psychotropic Substances Act, 1985 (NDPS Act) which is the anti-law of India. This act comes out to be very helpful for preventing India from drug abuse as it prohibits:

Cultivation of opium poppy, cannabis and cocoa plants, production, manufacture, possession, sale, purchase, transport, warehousing, use, consumption, import, export or trans-shipment of any narcotic drug or psychotropic substance except for medical and scientific purposes and as per the rules or orders and conditions of license issued. NDPS Act empowers central government to frame rules for certain purposes and state Governments to frame rules for certain others. Thus, there are NDPS Rules, 1985 of the Central Government and State NDPS Rules of different States. Violation of any rule of either the State or Central NDPS Rules attracts punishment under the NDPS Act. Any officer superior in rank to sepoy, peon or constable can seize drugs, materials used in their manufacture, controlled substances (i.e., precursors), conveyances, evidentiary material, etc. (Section 42). Any officer empowered under Sections 41 and 42 can detain, search and if he thinks proper, arrest, any person whom he has reason to believe to have committed an offence punishable under the Act (Section 42 (1) (d)). Any officer of the departments empowered to enforce NDPS Act can search, seize and arrest in public places (Section 43). Any officer authorized under Section 42 can stop, search, rummage and examine any animal or conveyance. He can compel the animal or conveyance to stop and if all lawful means of stopping it fail, he can fire upon such animal or conveyance (Section 49). Any gazette officer empowered under Section 42 ( or a magistrate) can attach illegally cultivated opium, cannabis or coca plants and order their destruction ( Section 48). Any officer empowered under Section 42 can during enquiry in connection with any contravention of any provision of the Act- 


\section{Police: A Savior to Drug Addicts}

o Call for information from any person

o $\quad$ Require any person to deliver any document or thing useful for the enquiry

o Examine any person acquainted with the facts and circumstances of the case (Section 67).

\section{Indian Laws to barricade drug-abuse}

Following Directive Principles of State Policy, UN Convention, the legal framework and the present scheme which are enacted as to prevent the coming generations from this evil should essentially be implemented:

The Constitution: Article 47 of the Constitution of India under the Directive Principles of State Policy directs the State to Endeavour to bring about prohibition of consumption, except for medicinal purposes, of intoxicating drinks and drugs which are injurious to health.

UN Conventions: The Government of India is a signatory to the following three UN Conventions on the subject:-

a) Single Convention on Narcotic Drugs, 1961, as amended by the Protocol of 1972 on Narcotic Drug

b) Convention on Psychotropic Substance, 1971, and

c) Convention on Illicit Traffic in Narcotic Drugs and Psychotropic Substance, 1988.

The NDPS Act, 1985: Article 253 of the Constitution empowers the Parliament to legislate for the purpose of discharging obligations under international conventions and foreign treaties. Accordingly, the Narcotics Drugs and Psychotropic Substances Act, 1985 was enacted in November, 1985, to give effect to the provisions of the existing UN Conventions. It contains stringent provisions for the control and regulation of narcotic drugs and psychotropic substances, and provides an essential framework and appropriate provisions for administrative action. 
Seal license of medical halls: On the investigation time, all those medical halls should be given the seal warrant on the trade of drugs.

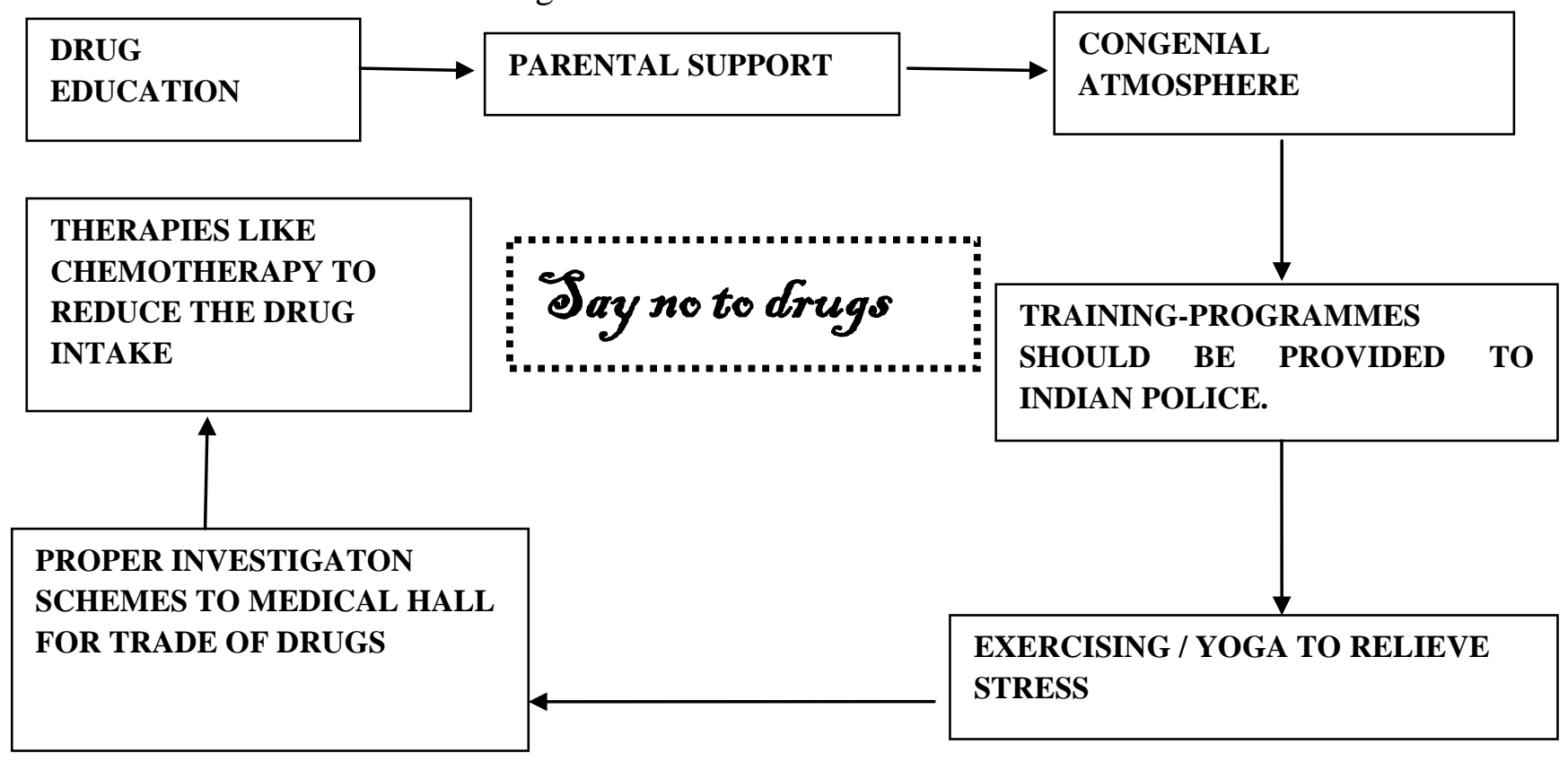

\section{Intelligence wing of India}

The Narcotics Control Bureau (NCB) is the intelligence agency of India responsible for fighting with drug abuse and illegal substances. The Narcotics Control Bureau was created on 17 March 1986 to enable the full implementation of the Narcotic Drugs and Psychotropic Substances Act, 1985 and fight its violation through the Prevention of Illicit Trafficking in Narcotic Drugs and Psychotropic Substances Act, 1988. The law was established to fulfill India's treaty obligations under the Single Convention on Narcotic Drugs, Convention on Psychotropic Substances, and Substances. Officers in this organization are drawn from Indian Revenue Service (I.R.S.) and Indian Police Service. 
Police: A Savior to Drug Addicts

Drug laws in India under centre for narcotic training national academy of custom, excise and narcotic, Faridabad:

OFFENCE

PENALITY

SECTION

\begin{tabular}{|l|l|l|l|}
\hline $\begin{array}{l}\text { Cultivation of opium, } \\
\text { cannabis or cocoa plants. }\end{array}$ & $\begin{array}{l}\text { Rigorous imprisonment up to 10 } \\
\text { Eears + fine up to 1 lakh } \\
\text { by licensed farmers. } \\
\begin{array}{l}\text { Financing traffic and } \\
\text { harboring offenders. } \\
\text { Repeat offence }\end{array}\end{array}$ & $\begin{array}{l}\text { Rigorous imprisonment up to 10-20 } \\
\text { years + fine up to 1-2 lakhs } \\
\text { Rigorous imprisonment up to 10-20 } \\
\text { years + fine up to 1-2 lakhs } \\
\text { One and half times the punishment } \\
\text { for the offence, death penalty in } \\
\text { some cases. }\end{array}$ & $\begin{array}{l}\text { Opium =18 (c) } \\
\text { cannabis = 20 } \\
\text { cocoa = 16 }\end{array}$ \\
Sec (19) \\
Sec 27a \\
Sec 30 \\
death 31-a
\end{tabular}

\section{More programs}

NATIONAL YOUTH ANTI-DRUG CAMPAIGN

Office of National Drug Control Policy: \$66.5 million (Reflects \$21.5 million increase over FY 2010) The Campaign uses media channels such as paid advertising, interactive media, and public information to educate and motivate youth to develop anti-drug beliefs and behaviors, and encourage adults to play a more effective role in keeping youth drug free. Funding (providing for television, radio, newspaper, Internet, and nontraditional advertising) enables the Media Campaign to address emerging drug issues among youth, such as prescription and over-the-counter drug abuse.

\section{Consolidated Tribal Grant Department of Justice: \$111.6 million (Reflects \$111.6 million} increase over FY 2010) The Department of Justice has set aside 7\% of the Office of Justice Program's (OJP) discretionary funding for grants or reimbursement programs under a new tribal criminal justice assistance program which consolidates previous OJP tribal funding streams and increases funding available for Indian Country public safety. In addition to funding grants to improve public safety outcomes in Indian Country, these grants will support training and technical assistance to improve tribal criminal justice outcomes, including drug and alcohol related issues. (This program has been scored evenly between Prevention efforts and Domestic Law Enforcement efforts.)

Drug Impaired Driving Program Department of Transportation: \$2.7 million (Reflects no change from FY 2010) The National Highway Traffic Safety Administration’s (NHTSA) FY 2011

(C) The International Journal of Indian Psychology, ISSN 2348-5396 (e)| ISSN: 2349-3429 (p) | 83 


\section{Police: A Savior to Drug Addicts}

request supports the Drug Impaired Driving Program, which will provide public information and outreach efforts, as well as improved law enforcement training in the area of drug-impaired driving. Funding will also support data collection efforts to better develop programs and countermeasures to address the problem. Arrestee Drug Abuse Monitoring II Program (ADAM) Department of Justice: \$10.0 million (Reflects \$10.0 million increase over FY 2010). In support of the fifth priority to create a permanent performance monitoring system, the FY 2011 request includes \$10 National Drug Control Strategy: FY 2011 Budget Summary 3 million for Justice to expand and enhance the Arrestee Drug Abuse booked arrestees in ten U.S. counties on their drug abuse and related behavior.

Therefore, with the help of this paper I dearth to put some light on how intelligence wing and police constables of our country should put their best efforts to eradicate the menace of drug from our country. Intelligence agencies like CBI, NCB etc should yield proper checks in the medical halls and medical factories to check the trade and they should seal the licenses given to these manufactures and dealers. Police constables must take bold step towards offenders to make our society menace free. Imprisonment for long years and deathly punishments should be given to criminals so that our up coming generations should be forewarned before committing any such tragic cries and use of these narcotic drugs.

\section{Acknowledgments}

The author appreciates all those who participated in the study and helped to facilitate the research process.

\section{Conflict of Interests}

The author declared no conflict of interests.

\section{REFERENCES}

Advani, R. (2013). Factors Driving Drug Abuse in India’s Punjab. Institute of South Asian Studies, 177. National University of Singapore.

Chandramouli, C. (2011). Census of India 2011 - Rural Urban Distribution of Population. Ministry of Home Affairs. New Delhi.

Chandramouli, C. (2011). Census of India 2011 (Provisional Population Totals): Punjab Profile. Ministry of Home Affairs. New Delhi.

Gerstein, D. \& Green, L. W. (Eds.). (1993) Preventing Drug Abuse. National Academy Press. Washington, DC

Hawkins, J.D., Catalano, R.F., \& Arthur, M. (2002). Promoting science-based prevention in communities. Addictive Behaviors, 90, (5) pp.1-26.

Ialongo, N., Poduska, J., Werthamer, L., \& Kellam, S. (2001). The distal impact of two firstgrade preventive interventions on conduct problems and disorder in early adolescence. Journal of Emotional and Behavioral Disorders, 9, 146-160, 


\section{Police: A Savior to Drug Addicts}

Johnston, L.D., O’Malley, P.M., \& Bachman, J.G. (2002). Monitoring the Future National Survey Results on Drug Use, 1975-2002. Vol 1: Secondary School Students. National Institute on Drug Abuse. Bethesda, MD

Kalra, I., \& Bansal, P.D., (2012). Sociodemographic Profile and Pattern of Drug abuse among Patients Presenting to a Deaddiction Centre in rural area of Punjab, Delhi Psychiatry Journal, 15 (2), pp.327-331.

Kumpfer, K.L., Olds, D.L., Alexander, J.F., Zucker, R.A. \& Gary, L.E. (1998)‘Family etiology of youth problems’ in R.S. Ashery, E.B. Robertson \& K.L. Kumpfer (eds.). Drug abuse prevention through family interventions, Research Monograph 177. National Institute on Drug Abuse. Rockville.

Ministry of Finance. (2013). Economic Survey 2012-13, Ministry of Finance. New Delhi.

Ministry of Youth Affairs and Sports. (2011). Awareness and Education for Prevention of Drug Abuse \& Alcoholism in Punjab. Nehru Yuva Kendra Sangathan. Punjab.

Nelson, J.E., Pearson, H.W., Sayers, M., \& Glynn, T.J. (1982). Guide to Drug Abuse Research Terminology. National Institute on Drug Abuse. Rockville.

Tandon, T.(2015). Drug Policy in India. International Drug Policy Consortium, pp.1-17

Wills, T., McNamara, G.. Vaccaro, D., \& Hirky, A. (1996). Escalated substance use: A longitudinal grouping analysis from early to middle adolescence. Journal Of Abnormal Psychology, 105, pp.166-180.

Wilson, J. Q. (1968). Varieties of police behavior. New York. Atheneum.

How to cite this article: R Sekhri (2016), Police: A Savior to Drug Addicts, International Journal of Indian Psychology, Volume 3, Issue 4, No. 60, ISSN 2348-5396 (e), ISSN: 2349-3429 (p), DIP: 18.01.085/20160304, ISBN: 978-1-365-26308-8 